\title{
Den topografiske vending og læring i praksis
}

\begin{abstract}
Introduktion
Humanvidenskaberne oplever aktuelt en rumlig vending (spatial turn), hvor opmærksomheden i stigende grad rettes mod betydningen af de konkrete fysiske rammer, som sociale interaktionsprocesser udspiller sig under (Casey 1996; Gulson \& Symes 2007). Interessen for rumlige forholds indflydelse på sociale og kulturelle processer skal i vid udstrækning ses som en reaktion på tendenserne til at negligere rummets betydning, som opstod i kølvandet på det, som Rorty formulerede som den sproglige vending (Rorty 1979).

I nærværende artikel vil vi betegne den aktuelle interesse for rumlige forhold som en topografisk vending (Hastrup 2004). Betegnelsen topografisk vending er udviklet af den danske antropolog Kirsten Hastrup, og er inspireret af Michel de Certeaus (1984) skelnen mellem forskellen på at ville studere kortet og ruten. Kortet udgør et totaliseret billede af verden, mens ruten angiver den faktiske bevægelse gennem den. I det øjeblik et sted bliver praktiseret, altså benyttet af mennesker, bliver det til et socialt rum. Det er årsagen til, at vi ikke kan nøjes med en kartografi, hvor omgivelserne beskrives objektivt og totalt. I stedet må vi have en topografi, der tager udgangspunkt i den sociale praksis' forankring i en konkret fysisk materialitet, som ændrer sig med tiden og i takt med de sociale praksisser, der udspiller sig i den (Hastrup 2004). Den topografiske vending lægger sig i forlængelse af diskussionen om rum og sted, som har udspundet sig internationalt inden for den seneste årrække, hvor forståelsen af rum som en neutral forudgivet størrelse, er blevet forladt til fordel for en forståelse af rum som et sted, hvor konkrete og praktiske handlinger genereres og finder sted (se Casey 1996 for en oversigt over rum- og steddiskussionen).
\end{abstract}

\section{Landskabsantropologien}

Den britiske antropolog og arkæolog Tim Ingold er en del af den såkaldte landskabsantropologi, der blomstrede op i 1990erne, hvor mennesker og deres land- 
skaber begyndte at blive tænkt sammen. Som udgangspunkt tager Ingold (2000) afstand fra at analysere et landskab som et objektivt rum eller som et subjektivt sted. Den analytiske distinktion mellem rum og sted (space and place) risikerer, ifølge Ingold, enten at føre til naturalistiske betragtninger af et landskab som et neutralt baggrundsbillede for menneskelig aktivitet, eller omvendt til et kulturalistisk perspektiv på landskabet som en kognitiv social orden. Et sted og et rum er, for Ingold såvel idemæssigt som materielt, en del af landskabet, som udgør en social helhed.

Inspireret af Heideggers (2000) skelnen mellem at bygge og bo i en bestemt verden er landskabet, for Ingold, den verden, man lærer at kende ved at opholde og bevæge sig på og mellem bestemte lokaliteter. Ingold udfordrer hermed det såkaldte byggeperspektiv. Ifølge byggeperspektivet former vi som mennesker mentalt repræsentationer af vores omgivelser, inden vi agerer i dem (Ingold 2000). Menneskets evne til at bygge er en konsekvens af vores evne til at forestille os og anticipere forskellige mulige udviklingsscenarier, og på baggrund af disse konstruere en bestemt forståelse af omgivelserne, som vi handler ud fra. Ifølge Ingold er socialvidenskaberne gennemsyret af dette byggeperspektiv, som for det første baserer sig på en problematisk adskillelse mellem det perciperende individ og den omverden der perciperes. For det andet er antagelserne i byggeperspektivet interessante i et pædagogisk perspektiv, da de lægger op til en dekontekstualiseret forståelse af læring og viden. Denne forståelse er bl.a. fremherskende i store dele af vores uddannelsessystems måde at tilrettelægge undervisning på, hvor læring i vid udstrækning anskues som et spørgsmål om tilegnelse af symbolske repræsentationer. Læring og tænkning gøres i denne forstålse til interne mentale processer, der foregår adskilt fra begivenhedernes gang i den omgivende verden.

Som alternativ til byggeperspektivet foreslår Ingold et beboerperspektiv (dwelling), hvor mennesket ikke forstås som et subjekt, der står overfor en objektiv verden. I stedet bebor mennesket altid den verden, som det indgår i praktisk engagement med. Tænkning og handling er i denne forstålse ikke to modsatrettede aspekter af den menneskelige væren - tænkning er derimod altid en integreret del af handling. Dette betyder, at de forestillinger, vi som mennesker danner os eller bygger, opstår i takt med vores praktiske engagement $\mathrm{i}$ konkret situerede aktiviteter. Vi eksporterer altså ikke planer eller mentale konstruktioner ind i den verden, som vi bygger. I stedet er det kun muligt at forestille sig, hvad vi vil bygge i verden, fordi vi allerede bebor denne verden. Mennesker lærer således at navigere i deres omgivelser i praksis. 


\section{Læring som en dvælende praksis}

Hvis vi igen vender os imod forskellige forståelser af læring, beskriver megen kognitivt inspireret læringsteori læreprocessen som en bevægelse, hvor individet begynder med at beskæftige sig med det konkrete, og herefter bevæger sig i retning af dannelse af abstrakte begreber (Lave \& Packer, 2008).

Inspireret af Heidgger og Ingold vil vi kort introducere en skitse til, hvordan læring ud fra beboerperspektivet kan forstås som en dvælende praksis. Heidegger bestemmer læring som "To learn means to make everything we do answer to whatever essentials address themselves to us at a given time" (Heidegger 1999a, p. 14). For at illustrere hvad han mener med læring, giver Heidegger et eksempel fra mesterlæren. Han bruger som eksempel en tømrerlærling, der skal lære at bygge et skab. Ifølge Heidegger er det centrale, at lærlingen lærer at være åben ('responsive') i forhold til det træ, som han arbejder med. Lærlingen skal lære at forstå at tilpasse sig træet som fænomen, og kun derigennem er det muligt for ham at blive tømrer. Det, der med andre ord konstituerer essensen i det som en tømrer skal lære for at blive tømrer, er en åbenhed over for træets essens, og det lærer en tømrerlærling kun ved at dvæle ved træet og forstå det som fænomen. Spørgsmålet er så, hvordan en lærling egentligt lærer at forstå træet som fænomen. Ifølge Heidegger foregår det gennem tilstedeværelsen af en lærer (eller en mester), der skal lære lærlingen at forblive åben over for træet som fænomen. Det centrale for læreren er i denne sammenhæng ikke, at vedkommende skal forsøge at formidle viden eller erfaringer til lærlingen. Det væsentligste og det vanskeligste for læreren er at sikre sig, at lærlingen forbliver åben og dvæler ved materialet eller fænomenet, hvilket bevirker at "Teaching is more difficult than learning because what teaching calls for is this: to let learn". (Heidegger 1999:14). Hvis vi tolker på Heidgegger, så bliver det centrale, at læreren hele tiden må sikre sig, at eleven selv gør sig forskellige former for erfaringer i den konkrete praksis.

I den sammenhæng er den amerikanske perceptionspsykolog J.J. Gibsons (1979) affordance-begreb (tjeneligheder) relevant, fordi han med det begreb søger at forstå menneskets forhold til den konkrete og levede omverden. Gibson bestemmer affordances som handlemuligheder, der ligger latent i omgivelserne. Affordances er uafhængige af det enkelte individs evne til mentalt at repræsentere $\mathrm{dem}$, men viser sig derimod når det enkelte mennesker handler $\mathrm{i}$ forhold til sine omgivelser. Gibsons teori søger at opbygge en anden forståelse af menneskets omverdensforhold end den dominerende kognitive teori, hvor verden fremstår for det enkelte menneske som tolkede formelle eller symbolske informationer. I stedet møder verden den enkelte som konkrete handlemuligheder. Dermed er vores opfattelse af omgivelserne baseret på, hvad disse omgivelser kan tjene os med. Vores 
perception er således ikke rettet mod, hvordan ting i verden er i sig selv. Den er derimod rettet mod, hvordan disse ting er relateret til os. Når jeg eksempelvis ser en trappe, ser jeg den i relation til mig selv. Det afgørende for om trappen udgør en trappe eller en forhindring, er ikke trappens fysiske dimensioner i sig selv. Derimod perciperer jeg trappen på baggrund af min krop. Endvidere søgte Gibson at formulere et alternativ til den forståelse, at mening eller det meningsskabende eksisterer i det enkelte menneske. Meningen eksisterer også i det kulturelle landskab, som møder, hvor allerede formerede artefakter netop er krystalliserede former for meningsfulde menneskelige aktiviteter (Costall 1995). Endvidere præciserer Gibson, at læring om affordances ikke er et spørgsmål om at lære, hvad genstande muligvis kan bruges til, men snarere er et spørgsmål om at finde ud af, hvilke typer af handlinger, affordances har til formål at fremme. Læring af affordances foregår oftest, ligesom pointeret gennem Heidegger, ved at vi bliver introduceret til dem. På trods af at affordances viser sig gennem handlinger, så viser de sig sjældent gennem egen afprøvning. I stedet foregår læring af affordances igennem skabelsen af bestemte former for sociale settings, hvor erfarne udøvere introducerer mindre erfarne til, hvordan artefakter og redskaber skal anvendes (Costall 1995).

\section{Landskabets temporalitet}

Ingold (2000) beskriver, at landskabet er temporalt, hvormed han mener, at mennesker, gennem deres praksisser, viderefører historiske processer i landskabet. Landskabet er dermed ikke en statisk enhed, men en dynamisk størrelse, der bliver levet som et 'work in progress' (Ingold 2000: 199). Landskabet afspejler altså det arbejde og liv, som tidligere generationer har lagt i det, men landskabet fornys samtidig konstant af de praksisser, der udspiller sig i det. Landskabets historicitet smelter således sammen med de sociale aktiviteter i landskabet. For at forstå temporaliteten i landskabet, er Ingolds begreb 'taskscape' relevant. Taskscape er Ingolds egen neologisme, men kan bedst oversættes som praksislandskab. Tasks er aktiviteter, der udføres på en sådan måde, at de har inkorporeret landskabet i sig (Ingold 2000; Agergaard, 2005). Ingold beskriver det selv på denne vis:

The landscape as a whole must likewise be understood as the taskscape in its embodied form: a pattern of activities 'collapsed' into an array of features. (Ingold 2000: 198).

Praksislandskabet er et mønster af aktiviteter, der er sammenfaldende med en række fremtrædende træk i landskabet. Som analyseredskab åbner praksislandskabsbegrebet op for at sammentænke aktørers praksisser i konkrete fysiske ram- 
mer med alt, hvad disse fysiske rammer repræsenterer af historie, tradition, udvikling, institutionelle strukturer, symbolske værdier og idealer osv.

For at eksemplificere praksislandskabsbegrebet vil artiklens empiriske afsnit illustrere, hvorledes der er indlejret forskellige værdier i de praksisser, der finder sted inden for landbruget.

Vi har valgt Ingolds Heidegger-inspirerede læringsforståelse og Gibsons affordancebegreb som illustrationer af, hvad der skal forstås med et topografisk perspektiv, hvor pointen er, at sociale praksisser er forankret i en fysisk materialitet, og at hverken de sociale praksisser eller den fysiske materialitet, som praksisser udspiller sig under, kan forstås uafhængigt af hinanden.

I det følgende vil vi anvende artiklens teoretiske pointer til at analysere et igangværende forskningsprojekt ${ }^{1}$ på en landbrugsskole for elever med indlæringsvanskeligheder.

Forskningsprojektet viser, at eleverne gennem deltagelse i et læringsmiljø med stærke læringsmæssige affordances bliver i stand til at realisere de læringspotentialer, som de aldrig har fået lejlighed til at udvikle i det etablerede uddannelsessystem. Disse elever, som alle har oplevet betydelige nederlag i folkeskolen, realiserer deres læringspotentiale, fordi de konkrete og praktiske læringsrum, som de indgår i, fungerer som stærke medspillere i deres læreprocesser.

\section{Havredal Praktiske Landbrugsskole og elever med indlæringsvanskeligheder}

Og da jeg så kom herop og gik rundt og kiggede på værkstederne, der begyndte jeg sådan at få et bedre indtryk af det fordi jeg kunne da godt se, at der sådan set ikke var noget klasseværelse her. Det var mere uden for det hele. Så begyndte gejsten at komme lidt tilbage for at fortsætte med at få uddannelsen.

Således beretter Carsten ${ }^{2}$ om sit første indtryk af Havredal Praktiske Landbrugsskole (HPL). Carsten er svært dyslektisk og kan hverken læse eller skrive. Han havde før sit møde med HPL gået på en almindelig landbrugsskole, men måtte efter to måneder droppe ud, da den teoretisk orienterede undervisning på uddannelsen blev for vanskelig. I stedet søgte han optagelse på Havredal Praktiske Landbrugsskole (HPL), som er en landbrugsskole for elever med indlæringsvanskeligheder. HPL fungerer som et moderne landbrug med både kvæg- og svinebesætning, hestelinje, samt $140 \mathrm{Ha}$ jord. Med inspiration fra mesterlæren driver skolens elever i fællesskab med lærerne landbruget. Elevmålgruppen på HPL er kende- 
tegnet ved ikke at kunne klare sig på det etablerede uddannelsessystems bogligt orienterede undervisningspræmisser. Det interessante ved HPL er imidlertid, at eleverne - på trods af deres status som elever med indlæringsvanskeligheder - får en formelt kompetencegivende uddannelse, idet eleverne tager det første modul af den almindelige landbrugsuddannelse, og dermed bliver landbrugsassistenter. Eleverne overskrider med andre ord det man kan forvente, at elever med indlæringsvanskeligheder kan realisere i løbet af et uddannelsesforløb. Som citatet fra Carsten antyder, tager eleverne ikke uddannelsen ved at sidde i et klasseværelse. I stedet bliver elevernes deltagelse i driften af landbruget godskrevet som undervisning. Dermed muliggør HPL, at elever, der hverken kan læse eller skrive, har mulighed for at tage en formelt kompetencegivende uddannelse.

\section{Malkegraven som Iæringslandskab}

For at illustrere en række centrale karakteristika ved den pædagogiske praksis på HPL, vil der i det følgende blive taget udgangspunkt i malkegraven som konkret læringslandskab. Malkegraven er valgt til en empirisk illustration af en række af artiklens teoretiske pointer, hvor vi vil analysere, hvordan en nystartet elev igennem sit ophold i malkegraven lærer at handle på de forskellige affordances i malkegraven. Herudover er malkegraven valgt fordi den spiller en central rolle på HPL. For det første beskriver forstanderen på HPL malkegraven som HPLs bedste læringsrum, fordi malkningen skal foretages to gange om dagen, 365 dage om året. Dette betyder, at alle eleverne på HPL får tid til at opøve rutiner i at malke. For det andet sælger HPL mælk for over 1 million kr. om året, hvilket betyder at malkegraven udgør et væsentligt indtjeningsgrundlag for landbrugsproduktionen på skolen.

For at analysere læringsmiljøet i malkegraven blev en nystartet elev, Lena, videooptaget på hendes første dag i malkegraven. For at få udviklingsperspektiv på Lenas læring i malkegraven, blev hun videooptaget en gang til en måned senere.

I det følgende beskrives Lenas første dag i malkegraven relativt detaljeret. Arbejdsdagen starter kl. 05.00 med at malkelæreren, John, ganske kort introducerer Lena til, hvordan malkeanlægget tændes og hvordan hun skal huske at føre en slange fra malkeanlægget ned i mælketanken. Herefter fortsætter de ned til malkegraven, som er en naturligt nedsunket platform, som gør, at malkeren kan malke køerne uden at skulle bukke sig ned. Malkegraven på HPL er en såkaldt sildebensmalkegrav, hvor 8 køer (4 i hver side) går ind på malkepladsen. Køerne står med yveret vendt mod malkegraven i en ca. 30 gradersstilling, således at de set ovenfra tager form som et fiskeskrog.

Lena og John går hen til den forreste ko. Alle køerne har et bånd viklet om 
benet, som indikerer, hvor meget kraftfoder de skal have. Den forreste ko har blåt bånd på, hvilket betyder at der skal rykkes tre gange i den snor, der giver den enkelte ko kraftfoder. Inden malkemaskinen sættes på yveret skal hver pat nøje rengøres med en varm, fugtig klud. Imens John forklarer Lena, hvordan hun skal tørre koens patter af, står han selv og tørrer en kos patter af. Han siger til Lena:

Der er en grund til, kluden har fire hjørner. Det er nemlig fordi, at der er et hjørne til alle koens fire patter.

Efter Lena har rengjort alle fire patter, skal hun inden hun sætter malkemaskinen på, tjekke mælkens konsistens og farve. Det gøres ved manuelt at frembringe 3-4 stråler fra hver pat.

Herefter skal malkemaskinen, som består af fire pattekopper sættes på koens patter. Malkemaskinen tager ca. fem minutter om at malke en ko.

I starten har Lena svært ved at få malkekopperne til at sidde fast. Hun suger for meget luft ind i malkemaskinen, og derefter kan kopperne ikke gribe fat om koens patter. Når malkningen er færdig, falder kopperne selv af patterne, og yveret skal efterbehandles med en bakteriebehandlende spray.

Da de er færdige med de fire køer i den ene side af malkegraven, lukker Lena køerne ud i stalden, inden de fire næste køer lukkes ind. På et tidspunkt, hvor alle fire køer i Lenas side har fået malkemaskinerne på, står hun og venter med hænderne i lommen. John kommer let smilende hen til hende og siger:

J: "Så er der en ting. Ved du hvad det er? Jeg er god til at sy. Hvis nu man har hænderne nede i lommerne, mens man er hernede, så syr jeg lommerne til."

L: "Ja."

J: "Når det bliver ti graders frost, så kan jeg forstå det, men ellers skal vi ikke have hænderne nede i lommerne."

Lena arbejder langsomt, men hun får bedre og bedre styr på at sætte malkekopperne på.

Da alle køerne er blevet malket bliver Lena introduceret til, hvordan anlægget skal rengøres. Alle malkemaskinerne samt det øvrige malkeudstyr skal vaskes, tørres og desinficeres efter hver malkning. Kl. 7:45 er malkningen overstået.

Da Lena bliver videooptaget en måned senere, starter hun selv malkeanlægget og går i gang med at malke køerne i hendes side af malkegraven. Hun arbejder fortsat relativt langsomt, men har fået et mere sikkert håndelag. Hun har arbejdet en tydelig rutine ind, hvor hun starter med at give alle fire køer $\mathrm{i}$ hendes side et ryk 
kraftfoder. Herefter vasker hun deres yvere, inden hun sætter malkemaskinerne på, og afslutter med at give dem mere kraftfoder.

\section{Affordances i malkegraven}

Rummet i malkegraven udgøres af en lang række affordances, der er med til at strukturere arbejdsgangen. Køerne træder ind i malkegraven med spændte yvere, som er slappe, når de forlader den, køerne har bånd om benene, der indikerer mængden af foder, malkemaskinerne hænger ned foran køernes yvere, malkemaskinerne siger en bestemt lyd, når de sættes på patterne, eller hvis de suger luft ind osv.

Gibsons teori (1979) om affordances er på mange måder radikal, fordi han argumenterer for, at affordances er direkte perciperbare. I forbindelse med analyserne af optagelserne i malkegraven faldt det os dog ind, at mange af de forskellige affordances i malkegraven først træder frem for Lena i takt med, at hun praktiserer malkningen. Så i stedet for at være direkte perciperbare, vil vi argumentere for, at en stor del af de forskellige affordances i malkegraven skal medieres. Malkelæreren, John, peger på de forskellige affordances i rummet, og Lena perciperer dem efterfølgende igennem sine handlinger. Som eksempel kan nævnes situationen med kluden, hvor John pointerer, at den har fire hjørner, fordi koen har fire patter. Før John gav Lena denne anvisning, havde hun startet inde på midten af kluden, og da hun kom til den 3. og 4. pat var kluden allerede mere eller mindre snavset over det hele. Med sine anvisninger lærer han Lena kludens affordances, og hun erfarer dem efterfølgende igennem sin praksis i malkegraven. Lenas læring i malkegraven drejer sig således om, at hun lærer at bruge rummet, så de forskellige affordances træder frem for hende. At Lena lærer at bruge rummet i takt med sit praktiske engagement blev tydeligt, da hun bliver videofilmet for anden gang. I løbet af sin måned i malkegraven har hun forbedret sig markant, men hun er eksempelvis også mere hjemmevant i malkegraven, hvilket viser sig ved, at hun praktiserer 'malkegravsjargonen' på lige fod med de øvrige elever. Bl.a. deltager hun i snakken om køer, som fortjener særlig opmærksomhed i forhold til eventuel yverbetændelse, ligesom hun eksempelvis omtaler en af køerne "Psykopatkoen", som er navnet på den ko i flokken, der ofte sparker malkemaskinen af.

\section{Malkegraven som kulturhistorisk landskab}

Malkning er et gammelt stolt håndværk med en lang kulturhistorie, som har rødder i landbokulturen. At lære at malke drejer sig således både om at opnå de tilstrække- 
lige tekniske malkefærdigheder. Men at blive god til at malke drejer sig i lige så høj grad om at arbejde i overensstemmelse med de værdier, som knytter sig til at opholde sig i og arbejde i en malkegrav. Disse værdier indebærer eksempelvis at møde til tiden, have en god omgang med dyrene, arbejde i et passende tempo, udføre arbejdet ordentligt, have en høj hygiejnestandard og så videre. Disse værdier kommer blandt andet til udtryk ved, at eleverne også forventes at tilegne sig bestemte kropslige holdninger til arbejdsopgaverne. At blive oplært i malkegraven drejer sig altså ikke kun om at lære at bruge de forskellige affordances, der tilbydes eleven. Der ligger også en implicit og usagt forventning på institutionen om, at eleverne viser bestemte kropsholdninger, der så igen henviser til et større sæt af livsværdier bundet til landbokulturen. Et konkret eksempel på de kropsholdninger, der forventes i malkegraven, som det er vigtigt at tilegne sig, beskrives i situationen, hvor Lena står med hænderne i lommerne, mens hun venter på, at malkemaskinerne falder af, og John beder hende om at få hænderne op af lommerne. John beder ikke Lena om at tage hænderne op af lommerne, fordi det forringer mælkens kvalitet, at hun står med hænderne i lommerne. Det handler snarere om, at John ved, at det ikke vil blive værdsat, hvis Lena står med hænderne i lommerne hos en kommende arbejdsgiver. Herudover provokerer det givetvis også John en anelse, da han selv er opvokset i en kultur, hvor man ikke står med hænderne i lommerne, når der arbejdes. I et efterfølgende interview blev John spurgt ind til episoden med hænderne i lommen, hvortil han svarede:

Altså om vinteren, når det er pivkoldt, så accepterer jeg det da også. Jeg går da også med hænderne i lommerne, ork. Men man skal passe på, at det ikke bliver en vane, fordi at det er ikke til gavn for nogen, og heller ikke for dem selv, overhovedet ikke.

Arbejdet i malkegraven drejer sig således ikke kun om at anvende de redskaber og arterfakter, der er til rådighed i landskabet. Det drejer sig også om at tilegne sig nogle ganske bestemte kropsholdninger (hænderne op af lommen) i forhold til de arbejdsopgaver, som eleven står over for. Eksemplet kan ligeledes tolkes som illustration af, hvordan landskabet med Ingolds ord, er temporalt. Som allerede beskrevet indebærer dette, at mennesker, igennem deres praksisser, viderefører historiske processer i landskabet. Praksislandskabet udtrykker med andre ord, at der i menneskers praksisser er indlejret en specifik kulturhistorie. Dermed lægger Ingolds tilgang op til at analysere malkegraven som et kulturhistorisk landskab, hvor den historiske kontinuitet og forandring sammenholdes (Ingold 2000). Det er dog vigtigt at pointere, at Ingolds praksislandskabsbegreb ikke har sit analytiske fokus på historien i sig selv, men derimod på den måde som historien er sammenholdt 
med de aktuelle praksisformer, som udspiller sig inden for landskabet (Ingold 2000; Agergaard 2005). I forhold til arbejdet i malkegraven er pointen således, at John, men også de ældre og mere erfarne elever, gennem deres praksisser i malkegraven inkorporerer og viderefører en række landbokulturelle værdier. Måden som disse værdier kommer til udtryk på udspringer således dels af en landbokulturel historisk tradition for, hvordan man (inter)agerer i et arbejdsfællesskab, og dels af, hvilke rammer malkegraven stiller til rådighed for de praksisser, der udspiller sig $\mathrm{i}$ den.

\section{Malkegraven som identitetsmarkør}

Lave \& Wenger (2003) betoner, at læring kan anskues som deltagelse i skiftende sociale praksisser. Lave \& Wenger beskriver videre læreprocessen som en rettethed mod at blive fuldgyldigt medlem af et praksisfællesskab. Men nok så interessant involverer bevægelsen mod fuldgyldig deltagelse af et praksisfællesskab en stærkere identitetsmæssig tilknytning til praksisfællesskabet. Lave \& Wenger (2003) fremhæver således, hvordan læring er knyttet tæt sammen med identitet. At bebo den verden, som vi tager del i, er ligeledes en identitetskonstituerende proces, hvor den enkelte bevæger sig mod at føle sig hjemme i den praksis, som vedkommende deltager i. Bl.a. har Löfgren (1997) tidligere tematiseret, hvordan der er forbindelser mellem udvikling af identitet og sted. Ved at være en del af arbejdet i malkegraven på HPL lærer Lena, som allerede beskrevet, ikke kun at malke. Hun kobler sig også identitetsmæssigt til malkegraven som læringslandskab, og derigennem indirekte til landbruget som erhverv. Når hun arbejder i malkegraven, indretter hun sin tilværelse efter malkningens rytme. Vækkeuret ringer klokken 04, hun tager sit arbejdstøj på, henter køerne på marken, malker køerne og gør endeligt anlægget rent. Herefter arbejder hun i stalden, sover til middag og gør klokken 15 klar til eftermiddagsmalkningen. Store dele af hendes tilværelse er altså rettet ind efter rytmen i malkegraven. Under et interview udtalte Lena:

Når jeg er i malkegraven, så føler jeg mig som en landmand.

Malkegraven og de praksisser, der udspiller sig i den, fungerer altså som en identitetsmarkør for Lena. Dermed skal Lenas identitetsudvikling forstås i lyset af, at hun deltager i en materielt situeret og lokaliseret praksis i malkegraven, som har en stærk værdimæssig tilknytning til et landbokulturelt praksisfællesskab. 
De ovenstående læringseksempler fra malkegraven tjener alle som eksempler på et topografisk perspektiv, hvor sociale processer antages at indgå $\mathrm{i}$ et dynamisk samspil med den konkrete og fysiske materialitet, som de udspiller sig inden for.

\section{Afrunding}

I denne artikel har vi på baggrund af Ingolds Heidegger-inspirerede læringsforståelse og Gibsons affordancebegreb argumenteret for, at læring er en situeret praksis, der skal forstås i relation til de fysisk-materielle omgivelser, som den udspiller sig under. Med udgangspunkt i et igangværende forskningsprojekt på en landbrugsskole for elever med indlæringsvanskeligheder har vi analyseret nystartet elevs læring i skolens malkegrav, og i den sammenhæng argumenteret for, at malkegraven skal analyseres som et kulturhistorisk landskab, hvor eleverne lærer at agere på baggrund af de læringsmæssige affordances, som stilles til rådighed i malkegraven.

\section{Litteratur}

Agergaard, S. (2005): At viderefore traditionerne. En etnografisk komparativ analyse af to danske idratsuddannelser for folkelige ledere og elitetranere. København. Multivers

Casey, E.S. (1996): "How to Get From Space to Place in a Fairly Short Stretch of Time", in Senses of Place, S. Feld and K. Basso (ed.), Santa Fe: School of American Research Press. pp. 13-52

Certeau, M. de. (1984): The Practice of Everyday Life. Berkeley, CA: University of California Press.

Costall, A. (1995) Socializing Affordances. Theory \& Psychology. Vol 5 (4): 467-481.

Gibson, J.J. (1979): The Ecological Approach to Visual Perception, Hilladale (NY), Lawrence Erlbaum.

Gulson, K.N. \& Symes, C. (2007): “Knowing one's place: space, theory, education”, Critical Studies in Education, Vol. 48 (1), 97-110.

Hastrup, K. (2004):'Introduktion. Antropologiens vendinger" i: Viden om verden. Hastrup, K. (red.). København, Hans Reitzels Forlag

Heidegger, M. (1999): What is Called Thinking. New York: Harper \& Row, Publishers Inc.

Heidegger, M. (2000, [1954]): "Tænke bygge bo" i Sproget og ordet. København: Hans Reitzels Forlag.

Ingold, T. (2000): The perception of the environment - Essays in livelihood, dwelling and skill. London: Routledge

Lave, J. \& Wenger, E. (2003): Situeret laring. København. Hans Reitzels Forlag

Lave, J. \& Packer, M. (2008): “Towards A Social Ontology of Learning”, i: K. Nielsen, S. Brinkmann, C. Elmholdt, L. Tanggaard, P. Musaeus \& G. Kraft (red.). A Qualitative 
Stance. Essays in honor of Steinar Kvale. Aarhus: Aarhus University Press.

Löfgren, O. (1997): Att ta plats: Rummets og rörelsens pedagogik, i G. Alsmark (red.). Skjorta eller Själ? Kulturelle identiteter i tid og rum. Lund: Studenterlitteratur.

Nielsen og Kvale, (2003): "Vandringer i praktikkens læringslandskab”, i: K. Nielsen \& S. Kvale. (2003) (red.): Praktikkens laringslandskab - At lare gennem arbejde. Kobenhavn: Akademisk Forlag.

Nielsen, N.K. (2005): Steder i Europa - omstridte byer, granser og regioner. Århus. Aarhus Universitetsforlag

Rorty, R. (1979): Philosophy and the Mirror of Nature. Princeton, NJ: Princeton University Press

\section{Noter}

1 Thomas Szulevicz er aktuelt i gang med et PhD-projekt, hvor han, med Klaus Nielsen som vejleder, undersøger den pædagogiske praksis på Havredal Praktiske Landbrugsskole.

2 Navnene i artiklen er anonymiserede. 